\title{
PORGAM CORPORATE SOCIAL RESPONSIBILITY PEMBERDAYAAN TKW PURNA BERBASIS UMKM
}

\author{
Oleh \\ Ade Iwan Ridwanullah \\ UIN Sunan Gunung Djati Bandung \\ Email: adeiwan@uinsgd.ac.id
}

\begin{abstract}
Research on Corporate Social Responsibility (CSR) for Empowerment of ex-female migrant worker (TKW Purna) based on UMKM as part of the excellent program of CSR's Pertamina RU VI Balongan, Indramayu, West Java Province. This activity program is motivated by the conditions of community in Indramayu as the second largest region in Indonesia female migrants worker (TKW) abroad who have also contributed to the number of total female migrant workers (TKW) which has an impact on the high rate of productive unemployment which is not matched by the availability of employment. The research method used is a qualitative descriptive method through interviews, field notes and documentation. The results showed that the empowerment of ex-female migrant worker (TKW Purna) based on UMKM was carried out through mentoring activities, creating Joint Entrepreneur Group (KUB) "Hawa Kreasi", financial assistantship, p-irt certification and package branding, entrepreneurship management training and marketing activities. The succeeded of these activities program is supported by factors that support activities including: resources, communication, and organizational structures that influence and strengthen each other.
\end{abstract}

Keywords : Corporate Social Responsibility, Female Migrant empowerment \& UMKM

\section{PENDAHULUAN}

Anggaran pendapatan belanja daerah merupakan dana yang diperuntukkan bagi Satuan Kerja Perangkat Daerah (SKPD) untuk melaksanakan berbagai kegiatan program serta meningkatkan pelayanan publik dalam rangka mewujudkan kesejahteraan dan aspirasi masyarakat. Satuan Kerja Perangkat Daerah yang menggunakan anggaran pendapatan belanja daerah salah satunya ialah Dinas Pendidikan Kota Bandung.

Dinas Pendidikan Kota Bandung merupakan satuan kerja perangkat daerah yang menggunakan anggaran pendapatan belanja daerah untuk memenuhi kebutuhannya yang bergerak di bidang pendidikan. Berdasarkan siklus pengelolaan keuangan daerah, dalam menggunakan anggaran Dinas Pendidikan Kota Bandung dimulai dengan perencanaan anggaran dan diakhiri dengan pelaporan serta pertanggungjawaban.

Perencanaan anggaran merupakan tahap awal dimana setiap satuan kerja perangkat daerah menyusun rencana pendapatan belanja untuk jangka waktu tertentu. Proses perencanaan anggaran ini berkaitan dengan bagaimana dan seberapa besar jumlah pengalokasian anggaran untuk setiap program dalam rangka melaksanakan tugas pokok dari Dinas Pendidikan Kota Bandung. Dalam mengelola anggaran, Dinas Pendidikan Kota Bandung mengklasifikasikan anggaran belanja ke dalam klasifikasi belanja langsung dan belanja tidak langsung dengan tepat agar pengelolaan anggaran dan pelaporan kinerja keuangan tercipta dan terlaksana dengan baik.

Perencanaan anggaran pada tahun 2013, Dinas Pendidikan Kota Bandung merencanakan anggaran sebesar Rp. 1.568.824.929. Di tahun 2014 merencanakan anggaran sebesar Rp. 1.875.954.198. Tahun berikutnya tahun 2015 mengalami peningkatan, Dinas Pendidikan merencanakan anggaran sebesar Rp. 1.951.494.820. Selanjutnya di tahun 2016 terus mengalami peningkatan dan perencanaan anggaran terbesar terjadi pada 
tahun ini sebesar Rp. 1.987.428.734. Dan tahun terakhir tahun 2017 perencanaan anggaran Dinas Pendidikan Kota Bandung mengalami penurunan yang sangat drastis, rencana anggarannya hanya sebesar Rp. 1.331.926.412. Dapat disimpulkan dalam kurun waktu lima tahun, Dinas Pendidikan Kota Bandung dalam merencanakan anggaran setiap tahunnya mengalami peningkatan.

Selanjutnya di dalam laporan keuangan Dinas Pendidikan Kota Bandung di dalamnya terdapat informasi perencanaan anggaran, realisasi anggaran, sisa anggaran dan seberapa besar persentase dari realisasi anggaran selama kurun waktu lima tahun. Pada tahun 2013 persentase realisasi anggaran Dinas Pendidikan Kota Bandung mencapai 93\% dengan perencanaan anggaran sebesar Rp. 1.568.824.929 dan realisasi anggarannya sebesar Rp. 1.460.452.056. Kemudian pada tahun 2014 persentase realisasi anggarannya menurun menjadi $86 \%$ dengan perencanaan anggaran yang meningkat sebesar Rp. 1.875.954.198 dan realisasi anggaran hanya sebesar Rp. 1.605.809.751. Pada tahun 2015 persentase realisasi anggarannya pun semakin menurun menjadi $84 \%$ dengan perencanaan anggaran yang semakin meningkat sebesar Rp. 1.951.494.820 dan realisasi anggarannya hanya sebesar Rp. 1.673.274.360. Kemudian pada tahun 2016 persentase realisasi anggarannya meningkat menjadi $85 \%$ dengan perencanaan anggaran Rp. 1.987.428.734 dan realisasi anggarannya sebesar Rp. 1.686.623.036. Selanjutnya pada tahun 2017 persentase realisasi anggaran 90\% dengan perencanaan anggaran sebesar Rp. 1.331.926.412 dan realisasi anggaran sebesar Rp. 1.199.461.863. Dari penjelasan diatas, dapat disimpulkan bahwa Dinas Pendidikan Kota Bandung dalam merencanakan anggaran dan merealisasikan anggaran kurun waktu lima tahun belum optimal.

Melihat perencanaan anggaran dan realisasi anggaran yang belum optimal, hal ini diduga dipengaruhi oleh kualitas laporan keuangan yang dihasilkan Dinas Pendidikan Kota Bandung pada periode sebelumnya. Merunut dari Laporan Hasil Pemeriksaan
(LHP) Pemerintah Kota Bandung Tahun Anggaran 2011-2016, laporan keuangan Kota Bandung masih mendapatkan opini Wajar Dengan Pengecualian (WDP). (Sumber: www.bandung.bpk.go.id )

Hal tersebut diakibatkan karena dinasdinas yang berada dibawah Pemerintah Kota Bandung belum melaksanakan tata kelola keuangan dan pelaporan yang optimal sehingga laporan keuangan yang dihasilkan belum memiliki kualitas yang baik termasuk Dinas Pendidikan Kota Bandung. Berdasarkan Laporan Kinerja Instansi Pemerintah (LKIP) Dinas Pendidikan Bandung menyatakan bahwa ada beberapa permasalahan yang dihadapi oleh bidang pendidikan salah satu diantaranya adalah pengelolaan keuangan yang belum transparan dan akuntabel yang mengakibatkan tingkat kewajaran laporan keuangan Dinas Pendidikan Kota Bandung masih mendapatkan opini Wajar Dengan Pengecualian (WDP). Dengan demikian, dapat disimpulkan bahwa permasalahan perencanaan anggaran yang belum optimal diduga karena laporan keuangan yang dihasilkan Dinas Pendidikan Kota Bandung pada periode sebelumnya belum memiliki kualitas yang baik.

\section{LANDASAN TEORI}

Administrasi publik menurut Dimock dan Koening dalam Lely Indah Mindarti (2016:4) menyatakan bahwa administrasi publik adalah kegiatan eksekutif dalam penyelenggaraan fungsi pemerintahan.

Laporan keuangan merupakan satu hal penting yang wajib ada baik di sektor publik ataupun swasta. Dan ada yang lebih penting lagi ialah kualitas dari laporan keuangan itu sendiri. Kualitas laporan keuangan menurut Suwanda (2015:68) adalah ukuran-ukuran normative yang perlu diwujudkan dalam informasi akuntansi sehingga dapat memenuhi tujuannya

Perencanaan anggaran menurut Bastian (2010:8) adalah penjabaran rencana yang mendetail atas pendapatan dan pengeluaran organisasi, agar pembelajaran yang dilakukan kemudian dapat dipertanggungjawabkan kepada publik. 
Adapun hubungan antara kualitas laporan keuangan dengan perencaaan anggaran diantaranya diungkapkan oleh Mardiasmo dalam buku Akuntansi Sektor Publik (2009: 165) mengungkapkan bahwa: Informasi akuntansi (laporan keuangan) diperlukan untuk perencanaan keuangan, menghitung biaya program dan penganggaran. Membuat anggaran membutuhkan pertimbanganpertimbangan teknis akuntansi yang matang. Dalam membuat anggaran, akuntansi dibutuhkan terutama untuk mengestimasi biaya program dan memprediksi kondisi ekonomi pemerintah dan perubahan-perubahan yang akan terjadi. Informasi akuntansi sangat membantu dalam pemilihan program yang efektif sesuai dengan kemampuan ekonomi pemerintah.

\section{METODE PENELITIAN}

Metode yang digunakan dalam penelitian ini adalah metode kuantitatif dengan pendekatan asosiatif. Teknik pengumpulan data yang digunakan adalah studi kepustakaan, observasi dan penyebaran kuesioner langsung kepada responden yang berjumlah 30 responden serta menggunakan teknik sampling jenuh.

Instrument yang digunakan dalam penelitian ini berbentuk angket/kuesioner dengan jumlah variabel sebanyak dua variabel. Dengan skala pengukuran yang digunakan adalah skala likert. Menurut Sugiyono (2016:165) mengungkapkan: Skala Likert adalah skala yang digunakan untuk mengembangkan instrument yang digunakan untuk mengukur sikap, persepsi, dan pendapat seseorang atau sekelompok orang terhadap potensi dan permasalahan suatu objek, rancangan suatu produk, proses membuat produk dan produk yang telah dikembangkan atau diciptakan.

Teknik analisis data yang digunakan dalam penelitian ini adalah uji regresi sederhana, uji regresi berganda, uji koefisien korelasi, uji $\mathrm{F}$, uji $\mathrm{T}$ dan uji determinasi menggunakan SPSS 17.

\section{HASIL DAN PEMBAHASAN Hasil Pengukuran Data Uji Validitas}

Uji validitas ini digunakan untuk mengetahui apakah alat ukur yang digunakan memiliki taraf ketepatan dalam melakukan pengukuran.

Berdasarkan hasil analisis didapat nilai korelasi antara skor item dengan skor total. Kemudian nilai ini dibandingkan dengan nilai $r$ yang ada di tabel, $r$ tabel dicari pada signifikansi 0.05 atau 5\% dengan uji dua sisi serta dengan jumlah data (n) sebanyak 30, maka didapatlah $r$ tabel sebesar 0,361. Berikut ini dapat dilihat hasil dari perhitungan uji validitas untuk keseluruhan butir pernyataan, sebagai berikut:

\begin{tabular}{|c|c|c|c|c|}
\hline Dimensi & Item & $\begin{array}{l}\mathbf{r} \\
\text { Hitung }\end{array}$ & $\begin{array}{l}\mathbf{r} \\
\text { Tabel }\end{array}$ & Keterangan \\
\hline \multirow{14}{*}{$\begin{array}{l}\text { Kualitas } \\
\text { Laporan } \\
\text { Keuangan }\end{array}$} & 1 & 0,578 & 0,361 & Valid \\
\hline & 2 & 0,576 & 0,361 & Valid \\
\hline & 3 & 0,682 & 0,361 & Valid \\
\hline & 4 & 0,670 & 0,361 & Valid \\
\hline & 5 & 0,785 & 0,361 & Valid \\
\hline & 6 & 0,728 & 0,361 & Valid \\
\hline & 7 & 0,758 & 0,361 & Valid \\
\hline & 8 & 0,485 & 0,361 & Valid \\
\hline & 9 & 0,433 & 0,361 & Valid \\
\hline & 10 & 0,525 & 0,361 & Valid \\
\hline & 11 & 0,632 & 0,361 & Valid \\
\hline & 12 & 0,447 & 0,361 & Valid \\
\hline & 13 & 0,446 & 0,361 & Valid \\
\hline & 14 & 0,396 & 0,361 & Valid \\
\hline \multirow{13}{*}{$\begin{array}{l}\text { Perencanaan } \\
\text { Anggaran }\end{array}$} & 15 & 0,670 & 0,361 & Valid \\
\hline & 16 & 0,562 & 0,361 & Valid \\
\hline & 17 & 0,458 & 0,361 & Valid \\
\hline & 18 & 0,466 & 0,361 & Valid \\
\hline & 19 & 0,737 & 0,361 & Valid \\
\hline & 20 & 0,670 & 0,361 & Valid \\
\hline & 21 & 0,862 & 0,361 & Valid \\
\hline & 22 & 0,494 & 0,361 & Valid \\
\hline & 23 & 0,775 & 0,361 & Valid \\
\hline & 24 & 0,436 & 0,361 & Valid \\
\hline & 25 & 0,814 & 0,361 & Valid \\
\hline & 26 & 0,701 & 0,361 & Valid \\
\hline & 27 & 0,857 & 0,361 & Valid \\
\hline
\end{tabular}


Berdasarkan hasil dari uji validitas didapat korelasi item pernyataan yang nilainya lebih dari sehingga dapat disimpulkan bahwa butir instr penelitian dari Variabel Kualitas Laporan Keuanga dan Variabel Perencanaan Anggaran (Y) dinyauanamil Analisis Data
Valid.

\section{Uji Reliabilitas}

Uji reliabilitas ini digunakan untuk mengetahui tingkat keterpercayaan atau ketepatan akurasi dari instrrumen penelitian dalam suatu ukuran. Untuk menguji keandalan dari suatu instrumen atau item-item pernyataan menggunakan metode konsistensi internal dengan menggunakan rumus Alpha Crombach yaitu perhitungan yang dilakukan dengan menghitung rata-rata interkorelasi diantara butir-butir pernyataan kuisioner. Nilai reliabilitas yang didapatkan dari penelitian ini dapat dilihat pada tabel berikut:

\begin{tabular}{|r|r|}
\hline Cronbach's Alpha & N of Items \\
\hline .857 & 14 \\
\hline
\end{tabular}

\section{Hasil Pengujian Reliabilitas Kualitas Laporan Keuangan}

Dengan pengolahan SPSS Versi 17, maka diperoleh nilai sebesar 0,857. Suatu variabel dikatakan reliabel jika nilai Cronbach's Alpha lebih besar dari 0,60. Karena nilai Cronbach's Alpha untuk kualitas laporan keuangan lebih besar dari 0,60 $(0,857>0,60)$ artinya variabel kualitas laporan keuangan reliabel. Sehingga dapat dikatakan bahwa seluruh instrumen layak digunakan ke pengujian selanjutnya.

\section{Hasil Pengujian Reliabilitas Perencanaan Anggaran}

Dengan pengolahan SPSS Versi 17, maka diperoleh nilai sebesar 0,884. Suatu variabel dikatakan reliabel jika nilai Cronbach's Alpha lebih besar dari 0,60. Karena nilai Cronbach's Alpha untuk perencanaan anggaran lebih besar dari $0,60(0,884>0,60)$ artinya variabel perencanaan anggaran reliabel. Sehingga dapat dikatakan bahwa seluruh instrumen layak digunakan ke pengujian selanjutnya. 
Dipahami (X4) terhadap variabel terikat yaitu Perencanaan Anggaran Dinas Pendidikan Kota Bandung. Berdasarkan hasil pengolahan data dengan bantuan software SPSS 17. Diperoleh4. hasil regresi sebagai berikut:

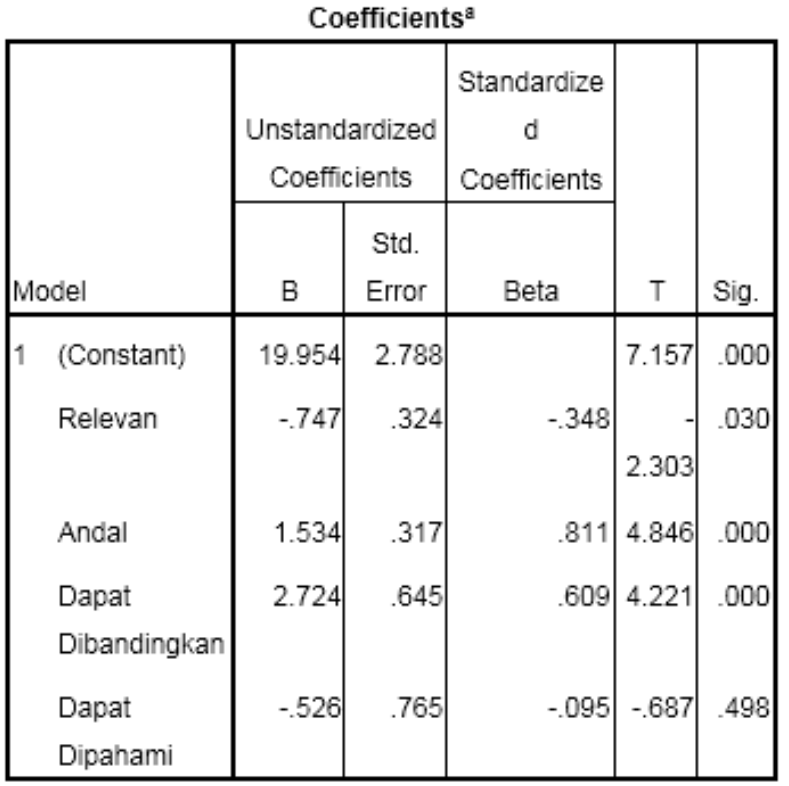

a. Dependent Variable: Perencanaan Anggaran

\section{Hasil Analisis Uji Regresi Linear Berganda}

Berdasarkan tabel hasil uji regresi linear berganda diatas, dapat diperoleh bentuk persamaan regresinya, yaitu sebagai berikut:

$\mathrm{Y}=\mathrm{a}+\mathrm{b} \mathrm{X} 1+\mathrm{b} \mathrm{X} 2+\mathrm{b} \mathrm{X3}+\mathrm{b} \mathrm{X} 4$ $Y=19.954+(-747 X 1)+(1.534 X 2)+$ $(2724 X 3)+(-526 X 4)$

Artinya:

1. Konstanta (a)

Konstanta sebesar 19.954 artinya kualitas laporan keuangan dalam skala interval adalah 19.954 jika tidak ada variabel relevan (X1), Andal (X2), Dapat Dibandingkan (X3), Dapat Dipahami (X4).

2. Nilai koefisien relevan (X1) sebesar (-747). Karena nilai mendekati angka 0 , mengindikasikan lemahnya hubungan antara variabel X1 dan Y. Artinya korelasi antara keduanya bersifat berlawanan. Artinya bahwa setiap laporan keuangan yang relevan mengalami peningkatan sebesar satuan dalam skala interval akan dibarengi penurunan perencanaan anggaran di Dinas Pendidikan Kota Bandung.

3. Nilai koefisien andal (X2) sebesar (1.534) artinya bahwa setiap peningkatan laporan keuangan yang andal sebesar satuan dalam skala interval akan meningkatkan perencanaan anggaran di Dinas Pendidikan Kota Bandung. Nilai koefisien dapat dibandingkan (X3) sebesar (2.724) artinya bahwa setiap peningkatan laporan keuangan yang dapat dibandingkan sebsar satuan dalam skala interval akan meningkatkan perencanaan anggaran di Dinas Pendidikan Kota Bandung. Nilai koefisien dapat dipahami (X4) sebesar (526). Karena nilai mendekati angka 0 , mengindikasikan lemahnya hubungan antara variabel X4 dan Y. Artinya korelasi antara keduanya bersifat berlawanan. Artinya bahwa setiap laporan keuangan yang dapat dipahami mengalami peningktan sebesar satuan dalam skala interval akan dibarengi penurunan perencanaan anggaran di Dinas Pendidikan Kota Bandung.

\section{Uji Koefisien Korelasi}

Uji Koefisien korelasi merupakan suatu uji yang menggambarkan apakah ada korelasi atau hubungan antara kualitas laporan keuangan terhadap perencanaan anggaran pada Dinas Pendidikan Kota Bandung. Dalam penelitian ini menggunakan teknik koefisien korelasi Product Moment, yaitu teknik yang digunakan untuk mencari hubungan dan membuktikan hipotesis hubungan dua variabel bila kedua variabel berbentuk interval atau rasio dan sumber data dari dua variabel atau lebih.

Dari tabel diatas dapat diketahui bahwa nilai koefisien korelasi Kualitas Laporan Keuangan tergolong kategori "Sangat Kuat" dan menunjukkan hubungan yang positif atau satu arah. Hubungan yang positif menunjukkan bahwa jika nilai Relevan, Andal, Dapat Dibandingkan, dan Dapat Dipahami meningkat maka Perencanaan Anggaran juga akan meningkat sebesar 0,975.

\section{Uji Signifikansi Pengaruh Simultan ( Uji F)}

Uji $F$ digunakan untuk mengetahui tingkat signifikansi pengaruh Relevan, Andal, Dapat Dibandingkan dan Dapat Dipahami secara simultan terhadap perencanaan anggaran. Uji F diolah dengan program SPSS 17 sebagai berikut: 
ANOVA $^{b}$

\begin{tabular}{|rl|l|l|l|l|l|}
\hline & $\begin{array}{l}\text { Sum of } \\
\text { Square } \\
\text { Model }\end{array}$ & & $\begin{array}{l}\text { Mean } \\
\text { Sqf }\end{array}$ & Square & F & Sig. \\
\hline $1 \quad \begin{array}{l}\text { Regre } \\
\text { ssion }\end{array}$ & 574.21 & 4 & 143.55 & 121. & .000 \\
Resid & 29.649 & 25 & 1.186 & & \\
ual & & & & & \\
Total & 603.86 & 29 & & & \\
\hline
\end{tabular}

a. Predictors: (Constant), Dapat Dipahami, Relevan, Dapat Dibandingkan, Andal

b. Dependent Variable: Perencanaan Anggaran

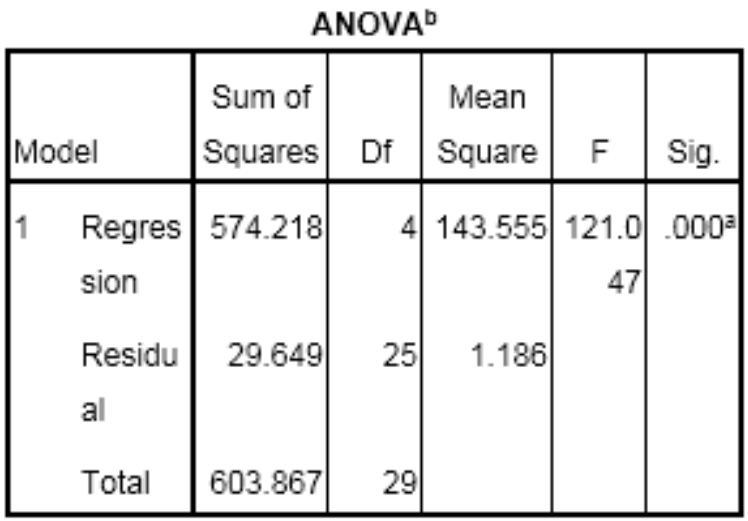

a. Predictors: (Constant), Dapat Dipahami, Relevan, Dapat Dibandingkan, Andal

b. Dependent Variable: Perencanaan Anggaran

\section{Hasil Uji F}

Dari tabel diatas diperoleh nilai $\mathrm{F}$ hitung untuk model regresi yang digunakan sebesar 121, 047. Untuk menentukan F tabel dengan menggunakan tingkat keyakinan sebesar $95 \%$, $\alpha=5 \%$, df1 $=(\mathrm{k}-1)=(4-1)=3$ dan df $2(\mathrm{n}-\mathrm{k})$ $=(30-4)=26$. Diperoleh hasil $\mathrm{F}$ tabel sebesar 2,98. Jika $F$ hitung $>F$ tabel $(121,047>2,98)$ maka Ho ditolak, artinya secara simultan ada pengaruh signifikan antara laporan keuangan yang Relevan, Andal, Dapat Dibandingkan dan Dapat Dipahami terhadap Perencanaan Anggaran di Dinas Pendidikan Kota Bandung.

\section{Uji Signifikansi Pengaruh Parsial (Uji T)}

Uji parsial atau biasanya lebih dikenal dengan uji $\mathrm{t}$ adalah suatu uji yang dilakukan untuk mengetahui pengaruh variabel kualitas laporan keuangan $(\mathrm{X})$ terhadap perencanaan anggaran (Y) secara rerpisah. Uji $t$ diolah dengan program SPSS 17 sebagai berikut:

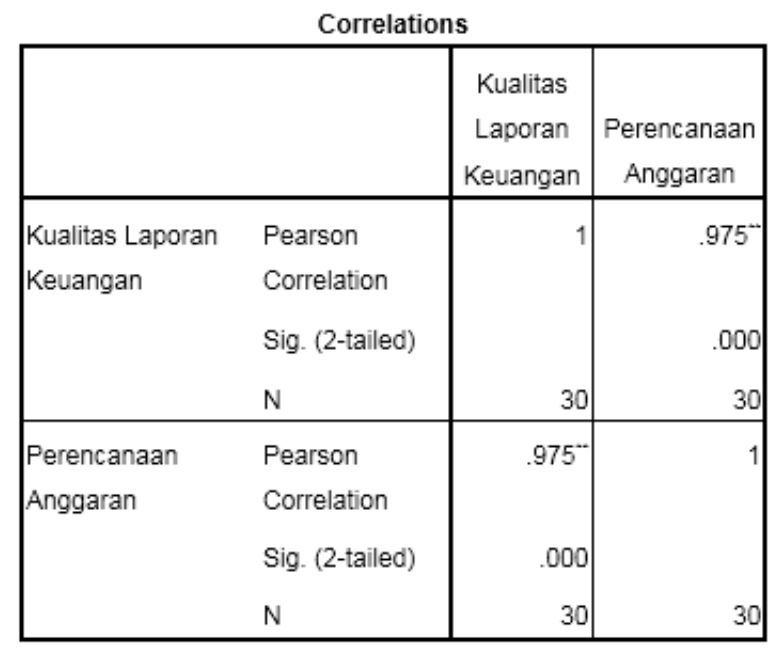

**. Correlation is significant at the 0.01 level (2-tailed).

Berdasrkan tabel pada Uji Regresi Linear Berganda diatas, dapat diketahui bahwa besarnya pengaruh laporan keuangan yang relevan, andal, dapat dibandingkan dan dapat dipahami terhadap perencanaan anggaran Dinas Pendidikan Kota Bandung sebagai berikut:

1. Pengaruh laporan keuangan yang Relevan terhadap Perencanaan Anggaran Dinas Pendidikan Kota Bandung

Dapat dilihat bahwa pengujian secara parsial memperoleh $\mathrm{t}$ hitung $>\mathrm{t}$ tabel $(-2.303>2.048)$ dengan taraf signifikansi sebesar 0,05 . Nilai $t$ negatif menunjukkan bahwa dimensi laporan keuangan yang relevan mempunyai hubungan yang berlawanan arah dengan perencanaan anggaran. Maka Ha diterima, artinya terdapat pengaruh yang signifikan antara dimensi laporan keuangan yang relevan terhadap perencanaan anggaran pada Dinas Pendidikan Kota Bandung.

2. Pengaruh laporan keuangan yang Andal terhadap Perencanaan Anggaran Dinas Pendidikan Kota Bandung

Dapat dilihat bahwa pengujian secara parsial memperoleh $\mathrm{t}$ hitung $>\mathrm{t}$ tabel $(4.846>2.048)$ dengan taraf signifikansi sebesar 0,05. Nilai t positif menunjukkan bahwa dimensi laporan keuangan yang andal mempunyai hubungan yang searah 
dengan perencanaan anggaran. Maka $\mathrm{Ha}$ diterima, artinya terdapat pengaruh yang signifikan antara dimensi laporan keuangan yang andal terhadap perencanaan anggaran pada Dinas Pendidikan Kota Bandung.

3. Pengaruh laporan keuangan yang Dapat Dibandingkan terhadap Perencanaan Dinas Pendidikan Kota Bandung

Dapat dilihat bahwa pengujian secara parsial memperoleh $\mathrm{t}$ hitung $>\mathrm{t}$

tabel $(4.221>2.048)$ dengan taraf signifikansi 0,05 . Nilai $\mathrm{t}$ positif menunjukkan bahwa dimensi laporan keuangan yang dapat dibandingkan mempunyai yang searah dengan perencanaan anggaran. Maka Ha diterima, artinya terdapat pengaruh yang signifikan antara dimensi laporan keuangan yang dapat dibandingkan terhadap perencanaan anggaran pada Dinas Pendidikan Kota Bandung.

4. Pengaruh laporan keuangan yang Dapat Dipahami terhadap Perencanaan Anggaran Dinas Pendidikan Kota Bandung.

Dapat dilihat bahwa pengujian secara parsial memperoleh $\mathrm{t}$ hitung $<\mathrm{t}$ tabel $(-687<2.048)$ dengan taraf signifikansi 0,05 . Nilai $t$ negatif menunjukkan bahwa dimensi laporan keuangan yang dapat dipahami mempunyai arah yang berlawanan dengan perencanaan anggaran. Maka Ho diterima, artinya tidak terdapat pengaruh yang signifikan antara laporan keuangan yang dapat dipahami terhadap perencanaan anggaran pada Dinas Pendidikan Kota Bandung.

\section{Uji Determinasi}

Analisis determinasi adalah untuk menunjukkan seberapa persen besarnya pengaruh kualitas laporan keuangan terhadap perencanaan anggaran pada Dinas Pendidikan Kota Bandung. Uji determinasi ini diolah dengan software SPSS 17 sebagai berikut:

\section{Hasil Uji Determinasi}

Berdasarkan tabel diatas, diperoleh $R^{2}$ (R Square) sebesar 0,951. Hal ini menunjukkan bahwa persentase sumbangan pengaruh kualitas laporan keuangan ssebagai variabel independen terhadap perencanaan anggaran sebagai variabel dependen sebesar 0,951 atau $95,1 \%$. Sedangkan sisanya sebesar $4,9 \%$ dipengaruhi atau dijelaskan oleh variabel lain diluar penelitian.

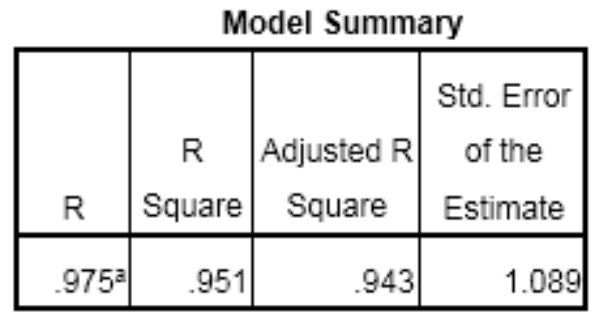

a. Predictors: (Constant), Dapat

Dibandingkan, Andal, Dapat Dipahami,

Relevan

\section{Hasil Penelitian}

Untuk mengetahui kondisi variabel kualitas laporan keuangan Dinas Pendidikan Kota Bandung maka peneliti melakukan pengukuran menggunakan kuesioner sebanyak 14 pernyataan yang masingmasing disertai 5 kemungkinan jawaban yang harus dipilih dan dianggap sesuai menurut responden. Setelah peneliti melakukan pengolahan data terhadap 14 pernyataan tentang kualitas laporan keuangan diperoleh hasi sebagai berikut:

\section{PENUTUP \\ Kesimpulan}

Berdasarkan hasil penelitian mengenai Pengaruh Kualitas Laporan Keuangan Terhadap Perencanaan Anggaran yang dilakukan melalui laporan keuangan, LAKIP, Rencana Kerja, Rencana Strategis dan penyebaran kuesioner di Dinas Pendidikan Kota Bandung, maka penulis memperoleh beberapa kesimpulan.

Berdasarkan hasil hitung statistik, disimpulkan bahwa:

1. Laporan keuangan yang Relevan, Andal, Dapat Dibandingkan dan Dapat Dipahami secara simultan terbukti berpengaruh signifikan terhadap Perencanaan Anggaran pada Dinas Pendidikan Kota Bandung. Dalam uji $\mathrm{F}$ diperoleh $\mathrm{F}$ hitung sebesar 121.047 dan nilai $\mathrm{F}$ tabel sebesar 2.98. Artinya $\mathrm{F}$ hitung lebih besar dar F tabel (121.047 > 2.98). Dengan demikian dapat 
disimpulkan bahwa hipotesis yang menyatakan adanya pengaruh laporan keuangan yang relevan, andal, dapat dibandingkan dan dapat dipahami secara simultan terhadap perencanaan anggaran Dinas Pendidikan Kota Bandung terbukti berpengaruh. Dengan nilai koefisien determinasi sebesar $95,1 \%$ dan sisanya sebesar $4,9 \%$ dipengaruhi oleh faktor lain yang tidak diteliti.

2. Berdasarkan hasil yang diperoleh dari kuesioner, dapat disimpulkan bahwa kriteria penilaian dimensi dengan persentase terbesar dari variabel kualitas laporan keuangan dan variabel perencanaan anggaran, diantaranya sebagai berikut:

a) Dimensi Relevan pada variabel kualitas laporan keuangan dengan pernyataan bahwa laporan keuangan Dinas Pendidikan Kota Bandung dapat dijadikan alat sebagai pengoreksi kesalahan-kesalahan di masa lalu dengan jumlah persentase sebesar 95,33\%.

b) Dimensi Perencanaan Jangka Pendek pada variabel perencanaan anggaran dengan pernyataan Dinas Pendidikan Kota Bandung mengalokasikan anggaran pada berbagai program atau kegiatan yang telah disusun dengan jumlah persentase sebesar $92,67 \%$.

3. Berdasarkan hasil yang diperoleh dari kuesioner, dapat disimpulkan bahwa kriteria penilaian dimensi terkecil dari variabel kualitas laporan keuangan dan variabel perencanaan anggaran, diantaranya sebagai berikut:

a) Dimensi Andal dengan pernyataan laporan keuangan Dinas Pendidikan Kota Bandung menggambarkan dengan jujur transaksi serta peristiwa lainnya dengan jumlah persentase sebesar $84 \%$.

b) Dimensi Perencanaan Jangka Panjang dengan pernyataan tujuan Dinas Pendidikan Kota Bandung telah sesuai dengan aspirasi masyarakat dengan jumlah persentase sebesar $78 \%$.
DAFTAR PUSTAKA

[1] Anggara, Sahya. 2016. AdministrasiKeuangan Negara. Bandung: Pustaka Setia

[2] Badrudin. 2013. Dasar-DasarManajemen. Bandung: Alfabeta

[3] Bastian, Indra. 2010. Akuntansi Sektor Publik: Suatu Pengantar. Jakarta: Erlangga

[4] Djarwanto. 2012. Pokok-pokok Analisis Laporan Keuangan. Yogyakarta

[5] Fahmi, Irham. 2017. Analisis Laporan Keuangan. Bandung: Alfabeta

[6] Hafiz, Abdul Tanjung. 2014. Akuntansi Pemerintahan Daerah Berbasis Akrual.Bandung: Alfabeta

[7] Hery. 2012. Analisis Laporan Keuangan. Jakarta: Bumi Aksara

[8] Indah, Lely Mindarti. 2016. Aneka Pendekatan dan Teori DasarAdministrasi Publik. Malang: UB Press

[9] Kencana. Inu Syafii. 2014. Ilmu Administrasi Publik. Jakarta: Rineka Cipta

[10]M. Nafarin. 2007. Penganggaran Perusahaan. Jakarta: Salemba Empat

[11] Mahmudi. 2013. Akuntansi Sektor Publik. Yogyakarta: UII Press

[12] Mahmudi. 2010. Analisis Laporan Keuangan Pemerintah Daerah. Yogyakarta: UPP STIM YKPN

[13]Mahmudi. 2016. Analisis Laporan Keuangan Pemerintah Daerah. Yogyakarta: UPP STIM YKPN

[14]Makmur. 2012. Filsafat Administrasi. Jakarta: Bumi Aksara

[15] Mamesah. 1995. Sistem Administrasi Keuangan Daerah. Jakarta: Gramedia Pustaka Utama

[16]Mardiasmo. 2009. Akuntansi Sektor Publik. Yogyakarta: ANDI

[17] Mursyidi. 2009. Akuntansi Pemerintah di Indonesia. Bandung: Refika Aditama

[18] Mursyidi. 2013. Akuntansi Pemerintahan di Indonesia. Bandung: Refika Aditama

[19]Pasolong, Harbani. 2013. Teori Administrasi Publik. Bandung: Alfabeta [20] Syafri, Wirman. 2012. Studi Tentang Administrasi Publik. Jakarta: Erlangga 
[21] Sugiyono. 2013. Metode Penelitian Kuantitatif, Kualitatif dan $R \quad \& D$. Bandung. Alfabeta

[22] Sugiyono. 2016. Metode Penelitian \& Pengembangan Research and Development. Bandung: Alfabeta

[23] Sugiyono. 2016. Statistika Untuk Penelitian. Bandung: Alfabeta

[24] Suwanda, Dadang. 2017. Strategi Mendapatkan Opini WTP. Jakarta: Salemba Empat

[25] Suwanda, Dadang. 2013. Sistem Akuntansi Akrual Pemerintah Daerah Berpedoman Berbasis Akrual. Jakarta: Ikrar Mandiri Abadi

[26] Syafri, Wirman. 2012. Studi Tentang Administrasi Publik. Jakarta: Erlangga

[27]Umam, Khaerul. 2012. Manajemen Organisasi. Bandung: Pustaka Setia

[28]Dwi, Aprianti Silvia. 2017. Pengaruh Laporan Keuangan Terhadap Perencanaan Anggaran Pada Dinas Pendidikan Kota Bandung. Skripsi. Universitas Islam Negeri Sunan Gunung Djati Bandung

[29] Gunawan, Agung. 2018. Pengaruh Laporan Keuangan Terhadap Akuntabilitas Pada Dinas

Perhubungan Kabupaten Bandung. Skripsi. Universitas Islam Negeri Sunan Gung Djati Bandung

[30] Syahrir, Syarif Malle. 2013. Analisis Faktor Faktor Yang Mempengaruhi Kualitas Informasi Laporan Keuangan Pemerintah Kota Makassar. Skripsi. Universitas Islam Negeri Alauddin Makassar.

[31] Undang-Undang Nomor 17 Tahun 2003 Tentang Keuangan Negara

[32] Peraturan Pemerintah No. 8 Tahun 2006 Tentang Pelaporan Keuangan dan Kinerja Instansi Pemerintah

[33]Peraturan Pemerintah Nomor 71 Tahun 2010 Tentang Standar Akuntansi Pemerintah

[34]Laporan Keuangan Dinas Pendidikan Kota Bandung

[35]Laporan Kinerja Instansi Pemerintah (LKIP) Dinas Pendidikan Kota Bandung
[36]Rencana Kerja Dinas Pendidikan Kota Bandung

[37]Rencana Strategi Dinas Pendidikan Kota Bandung

[38]BPK Perwakilan Provinsi Jawa Barat. 2017. LHP LKPD Kota Bandung. www.bandung.bpk.go.id diakses pada tanggal 11 Mei 2019 Pukul $\quad 10.43$ WIB

[39]BPK Perwakilan Provinsi Jawa Barat. 2018. Penyerahan LHP atas LKPD

TA 2017 pada Provinsi Jawa Barat dan 27 Pemda Kabupaten/Kota se-Jawa Barat. www.bandung.bpk.go.id diakses pada tanggal 28 Juni 2019 Pukul $\quad 11.14$ WIB

[40] Yulaika Ramadhani. 2018. PPDB Jabar 2018: Disdik Kota Bandung Tampung Setiap Pengaduan. https://tirto.id/ppdb-jabar-2018 disdikkota-bandung-tampung setiap pengaduan-Cn1z.com diakses pada tanggal 16 Juni 2019 Pukul 07.12 WIB 


\section{HALAMAN INI SENGAJA DIKOSONGKAN}

